\title{
Reinhold Niebuhr and Martin Luther King, Jr.: Christian Realism, Pacifism, and the Beloved Community
}

\author{
Daniel G. Lang \\ University of Lynchburg, Lynchburg, USA
}

\begin{abstract}
Reinhold Niebuhr's intellectual journey in the 1930's away from the idealism of liberal Protestantism and the optimism of the Social Gospel toward the more sober understanding of Christian realism involved, among other things, a rejection of pacifism. While conceding that the use of force in international relations is morally perilous, Niebuhr saw the utopianism of the pacifist position "to be nothing more than a capitulation to tyranny". Martin Luther King Jr. encountered Niebuhr's Moral Man and Immoral Society and other works in seminary a generation later. While he found much to praise in Niebuhr's analysis, ultimately he rejected Niebuhr's critique. Nevertheless, in spite of King's very public embrace of Gandhi's pacifism, one finds in King's practice of non-violent resistance substantial engagement with Niebuhr's ideas.
\end{abstract}

Keywords: Christian realism, utopianism, ethical dualism, pacifism, non-violent resistance

\section{Introduction}

Reinhold Niebuhr's intellectual journey away from the idealism of liberal Protestantism and the optimism of the Social Gospel toward the more sober understanding of Christian realism involved, among other things, a rejection of pacifism. While conceding that the use of force in international relations is morally perilous, Niebuhr saw the utopianism of the pacifist position "to be nothing more than a capitulation to tyranny". Martin Luther King Jr. encountered Niebuhr's Moral Man and Immoral Society, The Nature and Destiny of Man, and other works in seminary a generation later and came to credit Niebuhr's critique as one of the most important influences on his path to nonviolence. Niebuhr's "extraordinary insight" about the reality of sin on every level of human existence, wrote King, "helped me to recognize the illusions of a superficial optimism concerning human nature and the dangers of a false idealism" (King, 1958, p. 99). King contended that the path of non-violent resistance that he championed was a "realistic pacifism" that incorporated Niebuhr's insights and yet also addressed shortcomings in Niebuhr's position. The extent to which King's approach succeeded is the question this essay takes up. It begins with a description of Niebuhr's critique of utopianism and pacifism, then considers Niebuhr's influence on King with respect to the theory and practice of non-violent resistance, and concludes with a reflection on Niebuhr's continuing relevance for evaluating King's achievement.

\section{Niebuhr's Critique of Utopianism}

Niebuhr regarded as utopian those who contended for the establishment of a political order in which its

Daniel G. Lang, Ph.D., professor, Department of Political Science and International Relations, University of Lynchburg, Lynchburg, USA. 
members would "see and understand the interests of others as vividly as they understand their own" and where they have the moral goodwill that prompts them "to affirm the rights of others as vigorously as they affirm their own" (Niebuhr, 1932, p. xxxiv). What liberal democratic rationalists like John Dewey or religiously motivated adherents of the Social Gospel like Walter Rauschenbusch misunderstood was the way that human nature itself at once inspires and inhibits the realization of such an order. Utopians' misreading of human nature leads them into illusions about the possibilities and limitations about human action in the world. Individuals in their closest relationships can love and respect others, practicing the mutuality of which these utopians speak. However, to expect reason and moral goodwill or brotherly love to serve as the foundations for larger political communities is to ignore "the brutal character of the behavior of all human collectives, and the power of self-interest and collective egoism in all intergroup relations" (Niebuhr, 1932, p. xx). A too-consistent optimism about what people are capable of sooner or later gives way to a too-consistent pessimism when hopeful enthusiasm for change turns into bitter cynicism and withdrawal. Between these, Niebuhr argued for a Christian realism that holds that human beings are moral beings and that they can never really escape the power of self-love. The most fundamental truth about human beings is the truth we are naturally both free and finite. Our freedom consists in our ability to stand outside of our situation and to imagine how it might have been or could be different. This capacity for self-transcendence makes it possible for us to resist our instincts and break free of our particular circumstances to create new ideas, challenge prevailing patterns of thought, and establish a remarkable variety of social organizations. It enables us to make history rather than merely swim along in its flow. It fuels the hope that through education, the cultivation of social intelligence and the strengthening of the moral sense harmonious social relationships can be established and a just political order can emerge. It allows us to devote ourselves to a cause larger than ourselves and imagine that our actions might have world-historical significance. In short, utopian dreams may be said to be rooted in human nature itself as an expression of this capacity to re-create ourselves.

Yet humanity's capacity for self-transcendence is also the source of its undoing. For Niebuhr, there is no level of human moral or social achievement untainted by the corruption of inordinate self-love. The ability to stand outside and beyond the world "tempts man to megalomania and persuades him to regard himself as the god around and about whom the universe centers" (Niebuhr, 1941, p. 124). The self is still a mortal and finite self, unable to comprehend itself in its full stature of freedom. The awareness of its contingency-the realization that unlimited freedom is not possible for finite creatures - produces in the self a sense of insecurity and anxiety. The inevitable and unfortunate response to this insecurity is for the self to seek to overcome it either by denying the limits of its creatureliness, which in theological terms is the sin of pride, or in seeking to escape from freedom by finding a god in a person or process outside the self, the sin of sensuality or sloth (Niebuhr, 1941, pp. 185-186; Lovin, 1995, pp. 140-144). Pride reveals itself in overt ways through assertions of power over others and over nature itself; more insidious are the covert manifestations of intellectual pride and the "pride of virtue" or self-righteousness. Intellectual pride is the pride of reason which takes finite knowledge, gained from a particular perspective to be the final and ultimate knowledge; moral pride is "the pretension of finite man that his highly conditioned virtue is the final righteousness and that his very relative moral standards are absolute" (Niebuhr, 1941, pp. 194-199). The opposite temptation is to deny our freedom by immersing ourselves in those activities that require little of us and to focus primarily on our basic organic needs. This is the sin of "not doing what we ought to have done". The paradox at work in both pride and sloth is that the more we seek to transcend our finitude or deny our freedom, the more anxious we become and the more insecure we 
feel. And the more insecure we feel, the harder we try to overcome our limits or simply give in to the escapism of what is (Niebuhr, 1941, pp. 157-166; Lovin, 1995, pp. 149-154).

Human collectivities are the receptacles for both our self-giving and our power-seeking impulses. As naturally social beings, we require community. The individual cannot be a true self in isolation; it is only in responsible and mutual relations with our fellows that we can lead fulfilled lives. But the will to live that brings us together is inextricably linked with the will to power. Made anxious by the awareness of our freedom and potential perils to it, we seek to gain security by asserting our significance and enhancing our power. These assertions of power and prestige invariably encroach on the prestige and power of others. Conflicts ensue. Typically, these encroachments are justified in moral and ideological terms, raising the stakes and making resolution even more difficult. That is why, for Niebuhr, all social cooperation on a larger scale than the most intimate social group requires a measure of coercion. The presence of competing wills-to-power and the inevitability of divergent interests mean that some measure of force will need to be established and maintained. Political, legal, and moral institutions and processes may be developed that allow for ways to adjudicate and resolve conflicting interests, yet the coercive element is never absent. Even in democracies, there is a coercive as well as a moral element in their adoption of the majority rule principle. It may be that the majority is right, but it is also true that by virtue of its power the majority coerces the minority. The inevitability and the necessity of coercion are why, for Niebuhr, "Politics will, to the end of history, be an area where conscience and power meet, where the ethical and coercive factors of human life will interpenetrate and work out their tentative and uneasy compromises" (Niebuhr, 1932, p. 4).

Niebuhr's analysis of the rise, persistence, and moral limitations of the nation-state flow from this account of human nature. The capacity for self-transcendence made it possible for the human imagination to extend the natural organic feeling of family and tribe to larger units of cooperation, extending in the 19th century to the nation-state. There was in this development a significant moral element. For the individual, national loyalty can be a high form of altruism, commanding self-sacrifice in the name of a great cause. Paradoxically, such loyalty transmutes individual unselfishness into national egoism. The unqualified character of the individual's devotion to the nation then becomes the basis for the national authorities to use their power without moral restraint. Thus, the "unselfishness of individuals makes for the selfishness of nations" (Niebuhr, 1932, p. 91).

Like the individual, the nation-state gives in to the temptation to claim for itself a value more universal than its historical existence really permits. Through this claim, "human pride and self-assertion reach their ultimate form and seek to break all bounds of finiteness. The nation pretends to be God" (Niebuhr, 1941, I, p. 212). Armed with the coercive element of the police power and equipped with potent and vivid symbols that speak to self-giving passions, the nation-state has decisive advantages over other groups in securing individual loyalties. These encourage its pretensions to permanence. What lies beyond the nation, the community of mankind, is simply too vague to inspire devotion. Unfortunately, neither religious nor rational idealism can effectively check national egoism. The power and prestige of the international community is not significant enough to discipline recalcitrant nations. Nor can balances of power provide a guarantee of sustained stability. Thus, national self-assertiveness will continue; conflicts among nations will persist; and the resort to war will remain as a possibility. The best that can be expected of nations is that they can learn to do justice to wider interests, while they pursue their own (Niebuhr, 1932, p. 109). Unless one acknowledges the power of the particular, limited, and uniquely vital historical communities to work as centrifugal forces against the centralizing pressures of globalization and moral universalism, all efforts to establish global governance will 
fail. Yet, political realists who recognize only these centrifugal particularities and speak only of power and of balances of power miss the possibilities for establishing new structures of politics and open themselves to the danger of moral cynicism and giving up on justice altogether. Instead, world community must be built not by destroying self-interest, but by "deflecting, beguiling, and harnessing" it in working to establish significantly greater concurrence between self-interest and the general welfare (Niebuhr, 1946, pp. 153-162, 174-186).

\section{Niebuhr's Critique of Pacifism}

Having been a leader of the pacifist organization, the Fellowship of Reconciliation, during the 1920's, Niebuhr understood pacifism's appeal. The disillusioning experience of World War I, the Gospel admonition to love one's enemies, and the hope of secular rationalists that economic interdependence and technological change had made war obsolete fed in different ways pacifist hopes that the use of violence and war could be made a thing of the past if only humanity put its mind to it. As the decade wore on, however, Niebuhr increasingly distanced himself from this view. As a young pastor in Detroit, he saw firsthand the harshness of industrial society and the conflict between the workers and the propertied. What did the admonition to love one's neighbor mean in such circumstances? And what did it mean internationally with the onset of fascism in Italy, Japan, and Germany? By the time Moral Man and Immoral Society was published in 1932, Niebuhr had come to regard pacifism as a version of utopianism based on a shared misreading of human nature. The pacifist assumption that people are intelligent and moral and that treating others generously will help them discover and develop those qualities in themselves is partially true. Love, disinterestedness, and benevolence do have a strong social and utilitarian value. The moral principle of "Do as you would be done by" on which pacifism is based is rightly regarded as a significant moral achievement that should not be violated lightly. The pacifist's insight that violence tends to beget violence and arms build-ups on one side tend to result in arms build-ups on the other is not wrong. Once one sees, however, that the world of nature and history is a world in which individual and collective egoism will never be overcome, one must renounce the utopianism in pacifism (Niebuhr, 1932, p. 265; Niebuhr, 1957a, pp. 247-253; Niebuhr, 1957b, pp. 254-260).

Given the persistence of egoism, Niebuhr concluded that no society can exist without the use of coercive force nor could it trust all of its citizens to accept necessary social arrangements voluntarily. Moral suasion alone can only go so far; love cannot serve as a substitute for justice as the foundation for social relations. Christian pacifists are right when they insist that love is the ultimate law of life. What they have failed to realize is that the love for one's neighbor might oblige one to intervene coercively to protect him or her from harm. By prioritizing peace over justice, such pacifism results in the acceptance of injustice:

Capitulation to tyranny in the name of nonresistant perfection may be very noble for the individual. But it becomes very ignoble when the idealist suggests that others besides himself shall be sold into slavery and shall groan under the tyrant's heel. (Niebuhr, 1957c, p. 277)

Moreover, the moral absolutism reflected in some forms of pacifism commits the sin of self-righteousness. Its perfectionism is corrupted by its refusal to engage responsibly to preserve some relative decency and justice in society against tyranny and injustice. Justice, which involves making discriminate judgments between conflicting claims, is less than self-giving love because it assumes the power of self-interest, individually and collectively. Thus, the sinfulness of all men, even the best, makes justice between competing interests and conflicting wills a perennial necessity in history. The establishment of justice always involves a certain degree 
of pressure, of claims and counterclaims, of pushing and shoving, and the messy balancing of interests. There is an element of tragedy in this, "but any illusion of a world of perfect love without these imperfect harmonies of justice must ultimately turn the dream of love into a nightmare of tyranny and injustice" (Niebuhr, 1957d, p. 29).

In his critique of pacifism, Niebuhr noted that it came in several varieties. The purest form of pacifism is non-resistance. Essentially, non-resistance is withdrawal from society and the abandonment of all sense of social or political responsibility. This is the way of the mystic, the monk, and the martyr. Less extreme adherents of pacifism commit themselves to pursue social change but with non-violent means only. However, for Niebuhr "non-violence does coerce and destroy" and "the more intricate and interdependent the social process in which non-cooperation is used, the more certainly is this the case" (Niebuhr, 1932, p. 241). Niebuhr found confusing and misleading Gandhi's description of his non-violent approach as making use only of spiritual "soul force", as against physical "body force". As he saw it, Gandhi's method went beyond "spiritual" non-resistance to include forms of physical coercion as well. The marches, demonstrations, protests, boycotts, strikes, and acts of civil disobedience that Gandhi directed placed physical constraints on the freedom of others and imposed real costs. For example, the boycott of British cotton resulted in the undernourishment of children in Manchester, England, because of the loss of employment brought on by the boycott. These and the other measures Gandhi advocated clearly resulted in the suffering for others through the deprivation of services, unemployment, income loss, and even bloodshed. Innocents suffered along with the guilty. For Niebuhr this meant that the sharp distinction Gandhians drew between violent and non-violent methods was not as meaningful as they insisted. In his actions, Gandhi implicitly accepted the legitimacy of using coercion and "once we admit the factor of coercion is ethically justified, though we concede that it is always morally dangerous, we cannot draw any absolute line of demarcation between violent and nonviolent coercion" (Niebuhr, 1932, p. 172). From Niebuhr's point of view, all responsible leaders of a political community will need to use coercive means and, importantly, it can be morally responsible to do so. Since violence and revolution cannot be ruled out as immoral a priori, their possible use then becomes a question of political as well as moral judgment. In fact, Niebuhr praised Gandhi's political judgment and found much in his method to commend, though he thought Gandhi's conception of non-violence problematic. What Gandhi had shown is that non-violent resistance could work and be morally justified in certain circumstances. He had creatively opened up new possibilities for the oppressed to take action against their oppressors.

Implicitly, what Niebuhr's Moral Man and Immoral Society points to is a theory of justified coercion; explicitly it makes the case for nonviolent resistance in particular cases. A morally justifiable use of coercion - non-violent or violent — ought to begin with the motive of concern for the well-being of others and move to determine the right instrument for its goal and whether the objective is achievable. The choice of means certainly can condition the ends that can be achieved; in this, the use of non-violent resistance offers some real advantages as Gandhi's case illustrated. Gandhi's willingness to endure suffering and pain without striking back, his "cheerful submission" to punishment for deliberately breaking the law, his expressions of love for his adversaries, and his forgiving spirit made the negotiations between him and British officials less acrimonious. Violent conflicts always create resentments in both parties to a conflict, making accommodation more difficult. In the case of non-violent resistance, however, when the resisters have suffered more pain than they have inflicted, that spirit of resentment or vengeance is minimized. Negotiations and co-operation to reach new understandings become easier (Niebuhr, 1932, p. 251). Niebuhr also pointed out that Gandhi's method also 
allowed him to distinguish between the evils of a social situation and the individuals involved in it. Imperialism as a system was the problem, not the British individuals who found themselves having to defend it. Whether actually true or not, Gandhi's approach of not ascribing personal blame for the system to his British interlocutors wisely reduced the element of personal animosity which could easily get in the way. In short, non-violent resistance as a type of coercion offered promising opportunities for nurturing the moral and rational factors in social life, particularly in those cases where there is an oppressed minority that has no possibility of developing sufficient power to oppose its oppressors (Niebuhr, 1932, pp. 247-251).

In Moral Man and Immoral Society, Niebuhr drew particular attention to the possibilities of the strategy of non-violent resistance for the "emancipation of the Negro race in America". To rely on education and moral suasion alone to persuade white Americans was illusory; the "white race in America will not admit the Negro to equal rights if it is not forced to do so". Nor was violent revolution an option, since Negroes were hopelessly outnumbered and lacked significant economic resources. Their use of violence would "bring forth the most violent passions of which ignorant men are capable" (Niebuhr, 1932, pp. 253-254). However, Gandhi's methods could be adapted to fit American conditions and could make advances toward justice even against the selfish forces of an immoral society. Specific measures Niebuhr mentioned included boycotts against banks and other commercial interests that practiced discrimination and chose not to pay taxes to local governments to protest the severe underfunding of black educational institutions.

In this struggle, Niebuhr thought that the religious experiences of black America could serve as a useful imaginative resource on which to draw. The Christian faith they shared with their white co-religionists insisted on the transcendent worth of the individual, fostered attitudes of repentance which recognize that the evil in the foe is also in the self; dwelled on the possibilities in forgiveness; and nourished the impulses of love which claim kinship with all men. Taken to heart, these commitments could provide motives for action that would build up rather than tear down (Niebuhr, 1932, pp. 254-255).

To be sure, Niebuhr's qualified support for non-violent resistance did not mean that he regarded the use of violence as a morally impossible instrument of social change. The successful use of non-violent resistance depended in part on the response of the dominant group that was its target. Gandhi succeeded in India, in part, because the British had some degree of moral conscience. To advocate its use against totalitarian tyrannies like Nazi German or communist Russia was irresponsible because those regimes had clearly demonstrated their willingness to act ruthlessly against all opposition. The key question about revolution for Niebuhr was the purpose the use of violence would serve. He appreciated and used Marxist class analysis as a way to understand the advanced industrial societies of the West, yet he identified Marxists as "children of light" because of their romantic view of human nature. A violent revolution whose goal was to produce a new society whose members would be able to do whatever they wanted whenever they wanted and where the government would wither away because coercive means would no longer be necessary was clearly utopian and therefore not morally justifiable as a revolutionary goal. Indeed, it had already become clear to Niebuhr by 1932 that the Leninist "temporary" dictatorship of the proletariat could be extended indefinitely; it was bound to become a tyranny (Niebuhr, 1932, p. 194). By contrast, the American Revolution, though flawed in important respects, aimed at a possible dream, one consistent with human nature. Its purpose was not "the uncoerced and perfect peace and justice" but was instead the establishment of a society "in which there will be enough justice, and in which coercion will be sufficiently non-violent to prevent this common enterprise from issuing into complete disaster" (Niebuhr, 1932, p. 22). 
In summary, then, Niebuhr presented utopianism and pacifism as in tension with justice. Every structure of justice as embodied in political and economic institutions will "contain elements of injustice that stand in contradiction to the law of love" and every one will contain "higher possibilities" toward which those directing those institutions can strive. It is only when the mind "is not confused by utopian illusions" that it can "recognize genuine achievements of justice" and feel an obligation "to defend them against the threats of tyranny and the negation of justice" (Niebuhr, 1957e, p. 283).

\section{Martin Luther King's Reading of Niebuhr}

Like Niebuhr, Martin Luther King, Jr. came from a family of clergy. The son and grandson of Baptist ministers, King himself was ordained while an undergraduate at Morehouse College. He first encountered Niebuhr's work as a divinity student at Crozer Theological Seminary in 1951. At the time, he described himself as a liberal theologically and politically. Specifically, this meant for him rejecting a literalist reading of the Bible, embracing the methods of modern science, abandoning the doctrine of original sin, and accepting the teaching of the "Social Gospel" that "the gospel at its best deals with the whole man, not only his soul, but also his body" (King, 1958, p. 36). The "neo-orthodox" theologians he was introduced to in seminary, including Niebuhr, challenged these views. Instead, they emphasized the fragility of human reason, the transcendence of God, the persistence of sin, and the dangers of identifying any particular economic or political system with the Kingdom of God. In papers at the time and later in his published work, King wrote that these neo-orthodox perspectives had a chastening effect on him. He saw value in neo-orthodoxy's emphasis on the depth of human sin and the necessity of perpetual repentance, which also helped him to understand better "the race problem" that he had experienced. Nevertheless it remained his desire to be optimistic about human nature and hopeful about the possibility of social change (King, 1992a, pp. 251-256; King, 1992b, pp. 359-363).

How much influence Niebuhr's thinking actually had on King has become a matter of scholarly dispute; on the one hand, biographer Taylor Branch has argued that reading Niebuhr changed King's life; on the other, the editor of King's papers, Clayborne Carson, believes that King, ever attentive to his audience in his writing, exaggerated Niebuhr's impact (Carson, 1992, pp. 54-56; Branch, 1988, pp. 81-87). What King wrote in his "Pilgrimage to Nonviolence", is that he became so enamored in seminary of Niebuhr's social ethics "that I almost fell into the trap of accepting uncritically everything he wrote" (King, 1958, p. 97). In particular, he praised Niebuhr's insight into the complexity of human motives and his discussion of the complicated relationship between morality and power. Niebuhr, he said, had helped him to recognize the illusions of a superficial optimism concerning human nature, the dangers of a false idealism, and the glaring reality of collective evil. Against the rosy optimism of liberal theology, "[w]e have recognized that man has misused his kingly prerogative as a social animal by making others bear the burden of this selfishness". Accordingly, "the word sin must come back into our vocabulary" as at least part—and maybe the deepest part — of the explanation for many of the ills of the world (King, 1992c, p. 137).

Nevertheless, King pointed out that Niebuhr's analysis, while stimulating and profound, meant different ethical standards for individuals than for collectivities. Because agape love "must suffer in purity when taken into social relations", justice rather than love is the best a Niebuhrian can hope for in the social unit. Even a structure of justice based on the equality of rights and power would have to be regarded as morally inferior to a community of love. Love, which seeks out the needs of others, can move individuals to care about justice and 
it can also temper the self-righteousness to which justice is prone. The inevitable corruption of love into self-love, however, makes a reliance on love in social relations an "impossible possibility" (King, 1992d, pp. 141-151).

Ultimately, King found this approach too pessimistic about human nature and therefore insufficiently attuned to the transformative potential of agape love. Niebuhr, he found, tended to overemphasize the human inability to comprehend God's purposes for humanity and thus to overlook the cure of divine grace which can lift men out of "the sinful contradictions of history" and establish him "above the sins of the world". Through the practice of agape humanity is enabled to move toward the universal recognition of human dignity. Ours is a moral universe, hinged on moral foundations, and the arc of that universe is bending toward justice (King, 1992e, pp. 248-255). God works through history for the salvation of his children; he struggles with them against the forces of evil; and the moral laws that He has established will eventually defeat those who defy them (Ansbro, 1982, pp. 67-68).

King's commitment to the centrality of agape love as the foundation of ethical conduct pointed him toward nonviolence and pacifism. In light of Niebuhr's critique, however, he sought a "realistic" pacifism, one that would not claim to be without sin but which represented the lesser evil in the circumstances. Nevertheless, King said Niebuhr's critique of pacifism "left me in a state of confusion". And so it was that he turned to Gandhi's teachings on nonviolent resistance as the "only morally and practically sound method open to oppressed people in their struggle for freedom" (King, 1958, pp. 96-101).

King rejected Niebuhr's characterization of pacifism as an essentially passive non-resistance and insisted on the moral distinction between violent and non-violent resistance. Citing Gandhi's activism, King described the appropriate non-violent approach as the "courageous confrontation of evil by the power of love". While not physically aggressive toward his opponent, the non-violent resister's "mind and emotions are always active, constantly seeking to persuade his opponent that he is wrong". Side-stepping Niebuhr's observation that nonviolent resistance will necessarily involve elements of coercion, King stressed the moral importance of acting non-violently. When the non-violent resister expresses his protest through noncooperation, civil disobedience, demonstrations, strikes, and boycotts, these are to awaken a sense of moral shame in the opponent and thereby bring about a transformation and change in the opponent's heart. The possibility that nonviolent resistance opens up is a process of redemption and reconciliation that results in the creation of a community with love at its core, the "beloved community" (King, 1958, pp. 98-102).

King explicated the meanings of three Greek words for love: eros, philia, and agape. Eros is the yearning of the soul for the divine; philia is the love found in friendship; agape is the creative, redemptive good will toward all. At the center of nonviolence stands the principle of agape love. It enables us to love every man not because we like him or because his ways appeal to us but because God loves him. "It is the love of God operating in the human heart". Such love supplies others' need for community through its self-giving spirit, which dissolves the sentiments of mistrust and hatred that keep people from loving their fellow human beings. It "makes no distinction between friend and enemy", and it ultimately involves "a recognition of the fact that all life is interrelated ... and all men are brothers" (King, 1958, pp. 104-106). Applied to the American context, King pointed out how the system of racial segregation damaged the souls of the dominant white class along with those of the subordinate black one. Their personalities scarred by segregation, whites "need the love of the Negro" to remove the tensions, insecurities, and fears they felt. As they overcome their oppression by others, 
nonviolent resisters demonstrate their own dignity as human beings by mastering the passions of fear, self-pity, hatred, and vengeful anger. Thus their willingness to accept suffering without retaliation is redemptive for themselves as well as for their segregationist opponents (King, 1958, p. 106; Myers, 2003, pp. 666-686). Such sacrificial, selfless love makes possible the dream of a racially integrated America, a "beloved community" whose members "will not be judged by the color of their skin but by the content of their character". Whereas Niebuhr taught that justice was the negative application of love (using force to restrain the inordinate ambitions of individuals in the community), King embraced the power of agape to create genuine community with justice as its by-product.

Even though King laid out his principles of non-violence as an answer to Niebuhr's critique of pacifism and as an embrace of Gandhi's principles, his practice of non-violent resistance suggested considerable engagement with Niebuhr's ideas. As John Ansbro has pointed out, Gandhi stressed the necessity of self-purification and self-help programs as a condition for achieving political independence; King, on the other hand, became convinced that the American federal government could and should do more for African-Americans than they could do for themselves (Ansbro, 1982, pp. 141-145). While King did urge his followers to strive to be in good spiritual and bodily health and called on blacks to do more to improve themselves, he consistently and persistently sought ways to convince federal authorities to bring their power to bear against state and local ones. As we have seen, Niebuhr had set forward a theory of justified coercion using non-violent resistance with a significant religious component as his recommended option for African-Americans in their struggle against oppression. Niebuhr also taught that coercive measures would need to be brought to bear if greater respect for equal justice for American blacks were to come about. The non-violent campaign King undertook to end racial segregation, to secure voting rights for African-Americans, and to attack the causes of poverty show how a courageous, creative individual might apply Niebuhr's approach. This becomes clearer in the context of the Montgomery bus boycott, which, as Marshall Frady points out, set the pattern for King's subsequent campaigns (Frady, 2006, p. 41; Lemert, 2011, pp. 92-99).

\section{The Montgomery Bus Boycott}

In 1954, four years after first reading Niebuhr, King became pastor of Montgomery's Dexter Avenue Baptist Church. Barely a year later, he found himself thrust into leadership of the Montgomery Improvement Association, the organization brought to life by Rosa Parks' refusal to give up her seat on a segregated city bus and her subsequent arrest. As word of the arrest spread, the idea of a bus boycott quickly surfaced and alternative ways to transport black Montgomerians to and from work were devised. It was King's genius to characterize the boycott in moral terms as "non-cooperation with an evil system". Early on, he focused on the moral element: The purpose of the boycott was not to put the bus company out of business; it was to "put justice in business". In Niebuhrian fashion, King sought to mobilize the limited coercive means of the boycott on behalf of the morally praiseworthy end of equal justice. Niebuhr's analysis of power showed that all social structures involved a mixture of coercive and ethical-legal legitimizing principles and the defenders of those structures believe they reflect those principles better than they really do. King agreed; Jim Crow segregation showed how self-love distorted justice and deceived itself about the goodness of its intentions. As King observed of one of the white segregationist ministers he dealt with during the year-long crisis brought on by the boycott: The "isness" of segregation had for him become the "oughtness" of moral law. The fervor of that minister's denunciation of the boycott, compared with the tepid statements of support from white integrationists 
was, King observed, an example of the tragedy of history that "the children of darkness" are frequently more determined and zealous than the children of light (King, 1958, p.119). ${ }^{1}$

As King prepared to address the bus boycott's first mass rally, he confronted a basic dilemma: How to make a speech militant enough to mobilize and sustain the boycott and yet moderate enough to keep the fervor within controllable bounds? King's address sought to honor both freedom and finitude, the need for spirited action and the need for setting boundaries on that action. After reviewing the series of events that had sparked the boycott and raising questions about the legality of the city's segregation ordinances, King went on to insist first on the justice of the cause - "if we are wrong, God Almighty is wrong!"-and then on the importance of acting in love. Echoing Niebuhr, he said, "Justice is really love in calculation. Justice is love correcting that which would work against love" (King, 1958, pp.59-62; Branch, 1988, p. 141). The militancy that would come from dwelling on justice alone and that might lead to resentment, hatred, and acts of vengeance would be moderated by compassion for segregationists caught up in an evil system. Adding to the sense of moderation and "sweet reasonableness" was the fact that the demands of the Montgomery Improvement Association were also remarkably restrained. All that the boycotters were asking for was courteous treatment for all passengers, seating passengers on a first come first served basis, and hiring Negro bus drivers to drive the predominantly Negro routes. However, what King and his associates hoped would be a short-lived confrontation that would result in peaceful accommodationbecame instead a year-long ordeal due to the intractable resistance from the white establishment.

Victory eventually came because the nonviolent campaign combined moral and coercive elements; as Niebuhr had said, the white establishment would have to be forced to grant Negroes equal rights. In addition to the powerful moral example set by the non-violent resisters and their use of economic coercion against the bus company, King and his associates actively sought to involve the power of the federal government. In this case, that meant pursuing a ruling in the federal courts and eventually securing a Supreme Court decision that held legally segregated buses to be unconstitutional. Thus, the campaign relied both on the possibility of shaming its adversaries into acting decently and on the power the national government and the democratic principles of the American republic itself could exercise. King recognized that the coercion of the law alone would not be sufficient. The law, he noted, can keep a man from lynching another, but it cannot make that man love another. For that moral regeneration, the practice of self-giving love and forgiveness would be required.

King recognized that desegregation of schools and buses and full legal access to the public space alone would not be enough to secure civil rights. A closer approximation of justice required a shifting in the balance of power within society by admitting the disenfranchised into the political conversation. For King, what was needed was a revolution to "get in", not one to overthrow, the system. That meant securing the right to vote and then using it. In his "Letter From a Birmingham Jail", King reminded his readers of Niebuhr's observation that groups are more immoral than individuals and that history is the tragic story of the fact that privileged groups seldom give up their privileges voluntarily. Those who would make moral claims to their civil rights must gain the power to attain them (King, 1992f, p. 87; Diggins, 2011). As he argued in "Nonviolence: The Only Road to Freedom", "Our experience ... has been that a drive which registers Negroes to vote can do more to provide protection of the law and respect for Negroes by even racist sheriffs than anything we have seen" (King, 1992g, p. 129).

\footnotetext{
1 This, of course, was the theme of Niebuhr's book, The Children of Light and the Children of Darkness.
} 


\section{Non-Violence and the "Brotherhood of Man"}

As King's career progressed, his pacifism became more unyielding and his demands more radical. Throughout his career King defended the use of principled non-violent resistance in domestic protests; in later years, he increasingly applied the principle to international conflict as well. From a general condemnation of "militarism" in his 1964 Nobel Prize Acceptance Speech, King by 1967 had become an outspoken opponent of the U.S. involvement in Vietnam. In an address to the organization, Clergy and Laity Concerned, at the Riverside Church in New York, King linked the civil rights struggle and the movement against the Vietnam War. The war was diverting attention from the more urgent "war on poverty" and the American casualties were disproportionately African-American. The problem wasnot simply the injustice and foolishness of that particular war, but that war itself was obsolete. What he called for was a radical revolution in values against the "giant triplets of racism, materialism, and militarism". All over the globe, people were in revolt against old systems of exploitation and oppression and the United States found itself on the side of the developed, industrialized, colonialist West against them. As the richest and most powerful nation in the world, America could lead a revolutionary reordering of priorities "so that the pursuit of peace will take precedence over the pursuit of war". On the other side of this revolution would be a new America and a new world - a thoroughly, finally integrated world community bound by ecumenical, humanitarian love. It would be a "world-wide fellowship that lifts neighborly concern beyond one's tribe, race, class, and nation" based on "an all-embracing and unconditional love for all men". King provided no blueprint setting out the institutional details of this version of the "beloved community", but made it clear that he regarded the achievement of this new world as a real possibility. It is the way the arc of history bends. And he made it equally clear that he identified this new order with the embrace of a fully universalized Christianity and, at times, even with the immanent establishment of the Kingdom of God itself. Preaching to striking sanitation workers in Memphis on the evening before he was assassinated, King expressed his conviction that we, as a people, will get to the Promised Land". He knew this was so, he said, "because I've been to the mountaintop ... Mine eyes have seen the glory of the coming of the Lord!" (King, 1992h, p. 203)

It is hard to find much of Niebuhr in this vision, which from a Niebuhrian perspective, must be considered utopian. Niebuhr, as we have seen, like King, did pass judgement on the pride of nations and the perils of national self-assertion; he did embrace the "brotherhood of man" at some level; and he believed that a divine presence could enter human history. However, he also insisted that to the degree that steps could be taken to nourish a sense of world community, they should be taken in full awareness of the power of self-love and collective egoism. What countervailing centers of power did King think could be brought into being to challenge the power of the nation-state? Moral suasion alone-which seems to be what King was depending upon - hardly seems adequate. Moreover, Niebuhr pointed to a certain tension between justice and love. The agape love that King celebrated is disinterested, unselfish love; justice, on the other hand, involves the claims and counter claims of rights for oneself as well as for others. The persistence of self-interest and self-love is why the social unit can accommodate justice, not agape (Frady, 2006, p. 193). Following Niebuhr, one might say that there is a danger to justice itself as an unintended consequence of King's utopian vision. This concern is what animated Niebuhr's preference for a gradual approach to the civil rights revolution and his suspicion that relying on the authority of the Supreme Court alone would prompt a backlash (Diggins, 2011, p. 91). The more radical King's vision of integration became, the more it risked raising expectations that could not be 
achieved. For some, King's words are inspirational; for others, unmet expectations prompted by King's appeals may have contributed to continuing racial division, cynicism, anger, and despair (Myers, 2003, p. 685).

Niebuhr in Moral Man and Immoral Society directs much of the reader's attention to the false illusions and dangers of utopianism, yet he concludes the book by noting that there is something beautiful and humanly necessary in the tragedy of moral idealism or utopianism. His comment might serve as well for the judgment Christian Realism might make about King's non-violent resistance movement and the beloved community he hoped would issue from it. We live in an age, Niebuhr observed, when "personal moral idealism is easily accused of hypocrisy and frequently deserves it" and when "honesty skirts the edges of cynicism". This is tragic because what the individual conscience feels when it lifts itself above the world of nature and out of the web of its collective relationships is "a necessity of the soul". Having shed the false illusion that what is the way it ought to be, those consciences will recognize that they cannot "leave the total human enterprise unredeemed of its excesses and corruptions". The most effective agents of such moral idealism will be those who embrace a new illusion: that the life of mankind can achieve perfect justice. Though it is an illusion, it is a valuable one "for justice cannot be approximated if the hope of its perfect realization does not generate a sublime madness in the soul" (Niebuhr, 1932, p. 277).

\section{References}

Ansbro, J. J. (1982). Martin Luther King, Jr.: The making of a mind. Maryknoll: Orbis Books.

Branch, T. (1988). Parting the waters: America in the King Years. New York: Touchstone.

Carson, C. (1992). Introduction. In The papers of Martin Luther King, Jr. (Vol. 1, pp. 1-37). Berkeley: University of California Press.

Diggins, J. P. (2011). Why Niebuhr now. Chicago: University of Chicago Press.

Frady, M. (2006). Martin Luther King, Jr.: A life. New York: Penguin.

King, M. L. Jr. (1958). Stride toward freedom: The montgomery story. New York: Harper.

King, M. L. Jr. (1992a). How modern Christians should think of man. In C. Carson (Ed.), The papers of Martin Luther King, Jr. (Vol. 1, pp. 251-256). Berkeley: University of California Press.

King, M. L. Jr. (1992b). An autobiography of my religious development. In C. Carson (Ed.), The papers of Martin Luther King, Jr. (Vol. 1, pp. 359-363). Berkeley: University of California Press.

King, M. L. Jr. (1992c). Contemporary continental theology. In C. Carson (Ed.), The papers of Martin Luther King, Jr. (Vol. 2, pp. 359-363). Berkeley: University of California Press.

King, M. L. Jr. (1992d). Reinhold Niebuhr's ethical dualism. In C. Carson (Ed.), The papers of Martin Luther King, Jr. (Vol. 2, pp. 141-151). Berkeley: University of California Press.

King, M. L. Jr. (1992e). Rediscovering lost values. In C. Carson (Ed.), The papers of Martin Luther King, Jr. (Vol. 2, pp. 248-255). Berkeley: University of California Press.

King, M. L. Jr. (1992f). Letter from a Birmingham jail. In J. Washington (Ed.), I have a dream:Writing and speeches that changed the world (pp. 83-100). San Francisco: Harper.

King, M. L. Jr. (1992g). Nonviolence: The only road to freedom. In J. Washington (Ed.), I have a dream: Writing and speeches that changed the world (pp. 125-134). San Francisco: Harper.

King, M. L. Jr. (1992h). I see the Promised Land.In J. Washington (Ed.), I have a dream:Writing and speeches that changed the world (pp.193-203). San Francisco: Harper.

Lemert, C. (2011). Why Niebuhr matters. New Haven: Yale University Press.

Lovin, R. (1995). Reinhold Niebuhr and Christian realism. New York: Cambridge University Press.

Myers, P. C. (2003). The two revolutions of Martin Luther King, Jr. In B.-P. Frost and J. Sikkenga (Eds.), History of American political thought (pp. 666-686). Lanham, Md.: Lexington Books.

Niebuhr, R. (1932). Moral man and immoral society: A study in ethics and politics. New York: Scribner's.

Niebuhr, R. (1941). The nature and destiny of man, Vol. 1. New York: Scribner's.

Niebuhr, R. (1946). The children of light and the children of darkness. New York: Scribner's. 
Niebuhr, R. (1957a). Pacifism and the use of force. In D. B. Robertson (Ed.), Love and justice: Selections from the shorter writings of Reinhold Niebuhr (pp. 247-253). New York: Meridian Books.

Niebuhr, R. (1957b). Why I leave the F.O.R. In D. B. Robertson (Ed.), Love and justice: Selections from the shorter writings of Reinhold Niebuhr (pp. 254-260). New York: Meridian Books.

Niebuhr, R. (1957c). To prevent the triumph of an intolerable tyranny. In D. B. Robertson (Ed.), Love and justice: Selections from the shorter writings of Reinhold Niebuhr (pp. 272-278). New York: Meridian Books.

Niebuhr, R. (1957d). The ethic of Jesus and the social problem. In D. B. Robertson (Ed.), Love and justice: Selections from the shorter writings of Reinhold Niebuhr (pp. 29-39). New York: Meridian Books.

Niebuhr, R. (1957e). The Christian faith and the world crisis. In D. B. Robertson (Ed.), Love and justice: Selections from the shorter writings of Reinhold Niebuhr (pp. 279-284). New York: Meridian Books. 